\title{
CARCASS TRAITS, CECUM ACTIVITY, BLOOD METABOLIC PARAMETERS AND HISTOPATHOLOGICAL STATUS IN RABBITS FED JATROPHA (Jatropha curcas) SEED MEAL
}

\author{
K.M. Abd El-Rahman ${ }^{1}$, H.T. Taie ${ }^{1}$, G.A. Baraghit ${ }^{1}$, A.M. Soliman ${ }^{2}$ and Shereen A.I. Rabie ${ }^{2}$ \\ 1- Department of Animal Production, Faculty of Agriculture, University of Menofya, Egypt, 2- Department \\ of Animal Nutrition Research, Animal Production Research Institute, Dokki - Giza, Egypt \\ Email: D_kamalrahman2012@hotmail.com
}

Received : 29/8/2019

Accepted: 13/10/2019

\section{SUMMARY}

A total number of forty eight New Zealand White (NZW) rabbits 5 weeks of age and $683 \pm 28 \mathrm{~g}$ average live body weight were allotted at random to three similar experimental groups (of 16 rabbits each). Each group of rabbits was fed one of three experimental pelleted diets (16\% crude protein and $13 \%$ crude fiber on average). The feeding trail extended for 9 weeks. The aim of the study was to investigate the effects of partial substitution (50 or 100\%) of soybean meal of control diet with different levels of non toxic jatropha seed meal (JSM) as the sources for plant protein. on cecal activity, carcass characteristics, blood constitutions, and histopathological status. Results indicated no significant differences among the experimental groups in cecum activity. In addition, no significant differences among the experimental groups in serum total protein, albumin, globulin, serum aminotransferase (AST and ALT), creatinine and albumin $\mid$ globulin ratio were recorded, while urea- $N$ were significantly $(P<0.05)$ affected by different treatments. Hot carcass weight, dressing percentages and carcass characteristics were not significant, dressing percentage of rabbits fed diet containing 50\% JSM was (56.76\%) followed by diet that containing $100 \%$ (55.7\%), while the lowest value showed in control diet (55.30\%). No significant differences were found in chemical composition of fresh meat among the experimental groups. No significant differences among the experimental groups regarding platelets, MCV and MCH compared with the control group. There were no abnormalities, where hepatic architecture and hepatic lobules of histological structure of liver with no necrosis or cellular degeneration. There was no fatty liver observed. No abnormalities, there was only cloudy swelling to tubules in both treated and control groups in kidney.

It could be concluded that substitution of jatropha seed meal up to 50 or $100 \%$ of soybean meal in the diet of NZW rabbits had good results including carcass characteristics, blood constituent and histopathological status, without adverse effects.

Keywords: Jatropha seed meal, Cecum activity, Blood constituents, Carcass characteristics, Histopathology, Rabbits

\section{INTRODUCTION}

There is a shortage in animal protein in Egypt, rabbits could participate in solving this problem, but feed cost of rabbit production is still expensive. There are a large amount of crops, vegetables and fruit residues, which could be used as new sources of feedstuff with low price and high quality proteins to solve feed shortage and produce least cost diets for rabbits. A rapid increase in animal protein production at an affordable price is one of the pragmatic approaches of correcting this anomaly. This placed rabbit at a vantage position because they possess high fecundity, rapid growth, short generation interval and ability to utilize a lot of forage. Intensive rabbit production however requires concentrate pellet feed since forage alone cannot sustain the level of production of improved breeds of rabbit. The use of novelty plant protein crops has been suggested as a way of solving this problem. Jatropha is one of the numerous novelty crops that are promising in Egypt. This crop that belongs to the family of euphorbiaceae is gaining wider publicity due to the fact that its oil is being used for biodiesel production. One of the major by-products from jatropha seed is jatropha seed meal.
Jatropha seed cake by-product is rich in nitrogen and can be an excellent plant protein source (Makkar et $a l .$, 1998) and can spare the use of conventional plant proteins like soybean cake and groundnut cake if properly detoxified. However, the presence of antinutritional factors such as lectins, saponins, tannins, phytic acids, trypsin inhibitors, hydrocyanides and phorboesters is the greatest constrain to its use (Makkar and Becker, 1999). Different processing methods have been used to reduce the toxic compounds in jatropha seed meal. The use of jatropha seed cake meal will go a long way in solving pollution problem that is likely to attend the production of biodiesel on large scale. Histopathological studies also need to be an integral part of the studies for establishing the non-toxic nature of the detoxified products (Goel et al., 2007). The present research aims to investigate the effect of partial replacement of soybean meal instated of $(0,50$ and $100 \%$ ) on cecum activity, carcass characteristics, blood constituents and histopathological status of liver and kidney of growing New Zealand White rabbits. 


\section{MATERIALS AND METHODS}

\section{Animals and experimental design}

The present study was conducted at Animal Production Department, Faculty of Agriculture, Minufiya University Experimental station and the laboratory of Animal Nutrition Research Department, Animal Production Research Institute, Agriculture Research Center, Egypt.

The experiment was designed to evaluate the effects of partial substitution $(0,50$ or $100 \%)$ of soybean meal with non toxic jatropha seed meal (Jatropha ucrcas) (JSM) (Table 1). Forty eight unisexual growing NZW rabbits of 5 weeks old and $670 \pm 28 \mathrm{~g}$ average body weight, were randomly distributed and equally into three treatments groups, each of 16 animals. Each group was sub- divided into four replicates with four animals each. Rabbits were housed in wire floor batteries of $60 \times 55 \times 40 \mathrm{~cm}$. All batteries were located in a naturally ventilated windowed house. All animals were kept under similar hygienic conditions. Rabbits were offered diets for duration of the feeding trial until reaching 13 weeks of age. Removing poisonous materials from deeds were performed by extraction the oil from Jatropha fruits to the final products.

Table 1. Feed ingredients and chemical analysis of the experimental diets

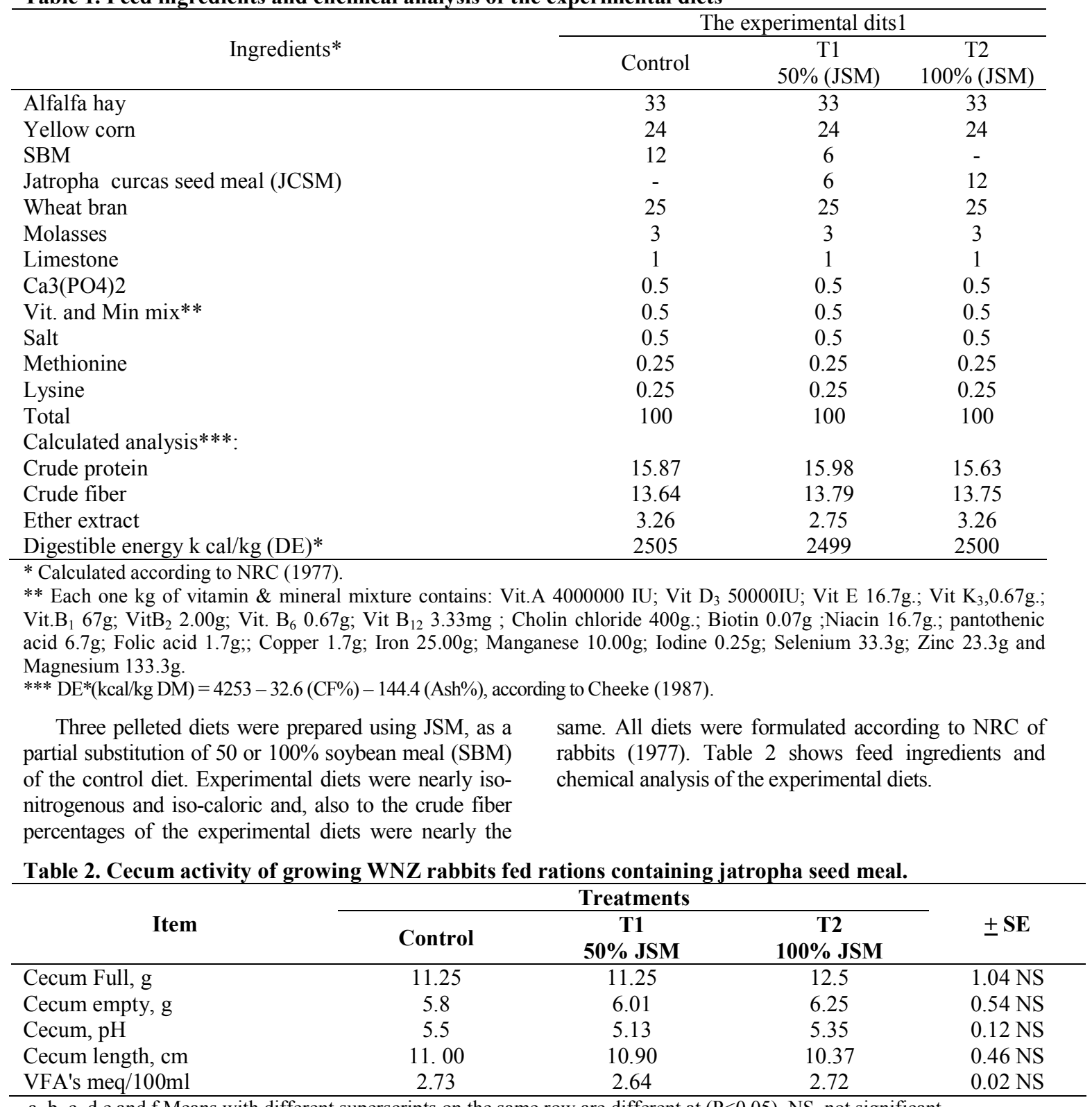

$\mathrm{a}, \mathrm{b}, \mathrm{c}, \mathrm{d}, \mathrm{e}$ and $\mathrm{f}$ Means with different superscripts on the same row are different at $(\mathrm{P}<0.05)$. NS, not significant 
Each group of rabbits was fed one of the three experimental diets. Fresh water was automatically available at all times through stainless steel nipples for each cage. The experimental diets were offered to rabbits ad libitum. The diets were adjusted every week according to the average daily feed intake. Individual live body weight and feed intake were weekly recorded up to 13 weeks of age.

\section{Blood samples:}

Blood samples were individually collected at 13 weeks of age from each rabbit in EDTA (ethylene-diamine-tetra acetic acid) bottles for analysis. The hematological examination was performed using an automatic multichannel blood cell counter (Systemx Kx 21 Haematology Analyser). The parameters included hematocrit value (HCT), red blood cell count (RBC), white blood cell count (WBC), hemoglobin (HG), mean corpuscular volume (MCV) mean corpuscular hemoglobin concentration (MCHC), platelets (PLT), and platelet cell distribution width (PDW). Determination of total red blood cells count was carried out according to the method of Dacie and Lewis (2000) and Ifeanyi (2015). Blood serum of other samples were separated by centrifugation at $3000 \mathrm{rpm}$ for 15 minutes. The collected serum was stored at $-18^{\circ} \mathrm{C}$ until analysis.

\section{Carcass traits:}

Ten rabbits were selected from each treatment for carcass evaluation. The rabbits were fasted overnight, weighed, slaughtered according to the Islamic rights, stunned, bled, cleaned and dressed. The edible and non-edible parts for the carcasses were recorded. Consequently, the head, fur, giblets (heart, liver and kidneys), lungs and viscera of the carcass were weighed. Hot carcasses were weighed and dressing percentages were calculated. For meat composition traits, all carcasses were divided longitudinally into two similar halves. The right half was physically separated into lean, fat and bone. Lean of each carcass was separated and prepared for chemical analysis.

\section{Cecum samples:}

The content of cecum of four rabbits from each treatment was obtained to determine the cecum weight, cecum length, $\mathrm{pH}$ value and volatile fatty acid (VFA's).

\section{Chemical analyses:}

Chemical analysis of the tested diets, ammonia nitrogen, TVF's and meat were carried out according to AOAC (2000). Blood serum samples were used to determine total protein according to Henry (1964); albumin according to Doumas et al. (1971); creatinine according to the method described by Bartels (1972); urea according to Patton and Grouch (1977). Liver function was assessed by measuring the activities of aspartate aminotransferase (AST) and alanine aminotransferase (ALT) according to Reitman and Frankel (1957) using commercial kits.
Cecum $\mathrm{pH}$ value was measured using $\mathrm{pH}$ meter (model HI8428). Diluted content of cecum and VFA's concentration were determined by steam distillation as mentioned by Eadie et al. (1967).

\section{Histological slide preparation and evaluation:}

Samples of liver and kidney were cut and fixed in $10 \%$ formalin solution for a week. The samples were washed in $50 \%, 70 \%$ and $90 \%$ alcohol for 2 hours each to remove water (dehydration). They were then transferred into xylene solution to get rid of the alcohol (clearing) and then infiltrated with paraffin wax and embedding media in an enclosure called mould (Amao, 2009). The embedded tissues were left until hardened blocks were formed. Sectioning was done using a microtome (Rotary Kepee Model KD 202A), to cut only the original tissue at a preset thickness of $5 \mu \mathrm{m}$. The sectioning was done serially and the products floated out in water bath. Satisfactory sections were then stained with haemato xylin and eosin on microscope slides. Finally, the slides were mounted on a microscope.

\section{Histological examination:}

The slides were read for histological indicators in order to observe possible degenerative changes on the liver and kidney structure using a microscope connected to a computer system. A photomicrographic software-Phoenix, Micro Image Analysis of Maity et al. (2013) version 1.3B was used to project the slides on the computer for clear assessment. The slides were subsequently captured and printed for interpretation.

\section{Blood serum analysis:}

Blood samples were collected from each rabbit with small needles and $5 \mathrm{ml}$ of the blood sample was kept in EDTA (ethylene-di-amine-tetra acetic acid) bottles for analysis. The hematological examination was performed using an automatic multichannel blood cell counter (Systemx Kx 21 Haematology Analyser). The parameters included hematocrit value (HCT), red blood cell count (RBC), white blood cell count (WBC), hemoglobin (HG), mean corpuscular volume (MCV) mean corpuscular hemoglobin concentration (MCHC), platelets (PLT), and platelet cell distribution width (PDW). Determination of total red blood cell count was carried out according to the method of Dacie and Lewis (2000) and Ifeanyi (2015).

\section{Statistical analysis:}

The data were statistically analyzed according to Snedecor and Cochran (1982) in one way analysis of variance design using SAS (1999) program as the model:

$Y_{i j}=M+A_{i}+e_{i j}$,

Where: $Y_{i j}=$ An observation, $M=$ Overall mean, $A_{i}=$ Effect of rations and $\mathrm{e}_{\mathrm{ij}}=$ Experimental error. 
The significant differences between means were tested using Duncan's multiple range test (Duncan, 1955).

\section{RESULTS AND DISCUSSION}

\section{Cecum activity}

Data presented in (Table 2) postulated some physical properties of cecum (full and empty weights as well as length), Table (2). Results indicated that the empty cecum of rabbits fed T1 and T2 diets was non-significantly heavier than the control diet, being 6.25 and $6.01 \mathrm{~g}$ vs. $5.89 \mathrm{~g}$. The cecum length $(\mathrm{cm})$ ranged between 11.0 and $10.37 \mathrm{~cm}$ without differences among treatments. Similar results were obtained by Ahmed (2010) who reported that cecum length of growing rabbit fed diets with medicinal plant ranged from 9.5-14 cm. Also El Sayaad et al. (1996) mentioned that the cecum weight increased in rabbits fed different CF levels with no significant differences.

Data of $\mathrm{pH}$ values ranged between 6.15 and 6.35 for all the experimental rabbits. The $\mathrm{pH}$ values ranged between 6.53 and 6.78 which are preferable to microorganism's fermentation in cecum and colon.

Concentration of the VFA's (meq/100 m cecum juice) as a microbial activities was 2.73, 2.64, 2.72 for control and T1 and T2, respectively. These values were nearly similar to those obtained by AbdelRahman et al., (2012) and_Mousa (2018) who stated that the VFA's values ranged between 2.11 and 2.73 $\mathrm{meq} / \mathrm{dl}$ for rabbits fed medicinal plant by-products. This result pointed out that all experimental diets had enough crude fiber and energy to keep good microbial activities in cecum. The findings by El manyalawy et al. (2005) indicated that cecum VFA's concentration did not increase in rabbits fed medicinal plants. In contrary, VFA's increased in rabbits fed medicinal plants by-product (Marty and Vernay, 1984 and Musa 2018).

\section{Blood parameters:}

\section{Hematological parameters:}

Data presented in (Table 3) revealed that there was no significant differences among the experimental groups regarding platelets, $\mathrm{MCV}$ and $\mathrm{MCH}$ compared with the control group. All of these values including control group run with the normal physiological values of rabbit as cited by Adjallo et al. (2017) who reported that honey derived from JCSM has no significant differences. Collectively, it could be established that incorporation of JCSM at different levels did not affect the blood parameters of rabbits compared with control group. Damage and destruction of the blood cells results in a variety of consequences such as a reduction in the oxygencarrying capacity of the blood, reduction in immune system function, and impairment of hemostatic function Adjaloo et al. (2017).

Table 3. Hematological parameters of growing WNZ rabbits fed rations containing jatropha seed meal

\begin{tabular}{|c|c|c|c|c|}
\hline \multirow[b]{2}{*}{ Item } & \multicolumn{3}{|c|}{ Treatments } & \multirow[b]{2}{*}{$\pm \mathbf{S E}$} \\
\hline & Control & $\begin{array}{c}\text { T1 } \\
50 \% \text { JSM } \\
\end{array}$ & $\begin{array}{c}\text { T2 } \\
100 \% \text { JSM }\end{array}$ & \\
\hline \multicolumn{5}{|c|}{ Hematological parameters: } \\
\hline Hemoglobin (g/dl) & 12.78 & 11.88 & 11.73 & $0.34 \mathrm{NS}$ \\
\hline $\operatorname{RBCs}\left(\times 10^{6} / \mathrm{ml}\right)$ & 5.05 & 5.12 & 4.65 & $0.32 \mathrm{NS}$ \\
\hline WBCs $\left(\times 10^{3} / \mathrm{ml}\right)$ & 7.05 & 10.2 & 8.12 & $0.12 \mathrm{NS}$ \\
\hline Platelets $\left(\times 10^{4} / \mathrm{ml}\right)$ & 30.5 & 28.9 & 28.9 & $0.17 \mathrm{NS}$ \\
\hline MCV (fL) & 78.3 & 73.4 & 74.2 & $2.43 \mathrm{NS}$ \\
\hline МCH (pg) & 25.53 & 24.00 & 23.47 & $2.86 \mathrm{NS}$ \\
\hline $\operatorname{MCHC~(g/L)~}$ & 32.57 & 32.68 & 32.51 & $2.95 \mathrm{NS}$ \\
\hline \multicolumn{5}{|c|}{ Metabolic blood parameters: } \\
\hline Creatinine (mg/dl) & 2.47 & 2.02 & 1.96 & $0.1 \mathrm{NS}$ \\
\hline Urea $(\mathrm{mg} / \mathrm{dl})$ & $63^{\mathrm{a}}$ & $53.5^{\mathrm{b}}$ & $57^{\mathrm{ab}}$ & $0.05^{*}$ \\
\hline AST u/l & 81.75 & 69.5 & 73.8 & $2.33 \mathrm{NS}$ \\
\hline ALT $\mathbf{u} / \mathbf{I}$ & 78.75 & 69 & 71 & $2.15 \mathrm{NS}$ \\
\hline Total protein g/dl & 6.24 & 5.86 & 5.81 & $0.06 \mathrm{NS}$ \\
\hline Albumin g/dl & 4.74 & 4.45 & 4.17 & $0.74 \mathrm{NS}$ \\
\hline Globulin $\mathrm{g} / \mathrm{dl}$ & 1.37 & 1.40 & 1.31 & $0.03 \mathrm{NS}$ \\
\hline A/G ratio & 3.39 & 3.35 & 3.21 & $0.01 \mathrm{NS}$ \\
\hline
\end{tabular}

$\mathrm{a}, \mathrm{b}, \mathrm{c}, \mathrm{d}, \mathrm{e}$ and $\mathrm{f}$ Means with different superscripts on the same row are different at $(\mathrm{P}<0.05)$. NS, not significant

\section{Blood metabolites:}

Data presented in (Table 3) illustrated that some metabolic enzymes such as aspartate aminotransferase (ALT) exhibited insignificant activities in rabbits fed diets containing two levels (50 or $100 \%$ ) of JSM which reflect a better function of liver. Values of both enzymes lie between the normal ranges without any adverse effect on the experimental rabbits. These results are in agreement with the findings of Hamoda (2010). Also, there were no significant differences in serum concentration of total protein, albumin, globulin and the ratio between albumin to globulin $(\mathrm{A} / \mathrm{G})$ of rabbit fed experimental diets, this means that both proteins of SBM and JSM 
had similar effect on protein synthesis and metabolism.

Feeding growing rabbits on diets containing control, 50 and $100 \%$ JSM had no problems with kidney function. Creatinine and urea levels in blood are used as measures of kidney function as these substances are excreted by the kidney. Creatinine is a more specific marker for kidney function as noticed by Koffuor et al. (2011) and Abdel-Rahman et al., (2012)

Serum urea concentration significantly $(\mathrm{P}<0.05)$ decreased with 50 and $100 \%$ JSM groups. The increase in urea in control group could be explained by a relative protein shortage in the control diet. The same trend was reported by Adjaloo et al. (2017) who reported that, there were no significant change in kidney function between control and treated groups with phorbal easter groups (ranged between $300-800 \mathrm{mg} / \mathrm{kg}$ body weight) as indicated by plasma urea and creatinine measured in rats. Habeeb et al., (1997) reported that, serum urea levels were 1.4

Table 4. Dressing percentage and carcass offal's of slaughtered growing WNZ rabbits fed rations containing jatropha seed meal

\begin{tabular}{|c|c|c|c|c|}
\hline \multirow[b]{2}{*}{ Item } & \multicolumn{3}{|c|}{ Treatments $^{1}$} & \multirow[b]{2}{*}{$\pm \mathbf{S E}$} \\
\hline & Control & $\begin{array}{c}\text { T1 } \\
50 \% \text { JSM } \\
\end{array}$ & $\begin{array}{c}\text { T2 } \\
100 \% \text { JSM } \\
\end{array}$ & \\
\hline Pre-slaughter wt., g & 2357 & 2335 & 2112 & $3.17 \mathrm{NS}$ \\
\hline Empty carcass, $g$ & 1315 & 1301 & 1208 & $3.05 \mathrm{NS}$ \\
\hline Dressing, $\%$ & 55.3 & 55.7 & 56.76 & $2.54 \mathrm{NS}$ \\
\hline Liver, $\mathbf{g}$ & 60 & 65 & 55 & $2.34 \mathrm{NS}$ \\
\hline Heart, g & 10 & 8.75 & 5 & $0.02 \mathrm{NS}$ \\
\hline Kidneys, $\mathbf{g}$ & 15 & 17.5 & 12.5 & $0.65 \mathrm{NS}$ \\
\hline Lung, $g$ & 14 & 16.25 & 15 & $0.21 \mathrm{NS}$ \\
\hline Total giblets, $\mathrm{g}$ & 301 & 225 & 273 & $3.02 \mathrm{NS}$ \\
\hline \multicolumn{5}{|c|}{ Meat chemical composition On DM basis } \\
\hline $\mathbf{C P}$ & 73.89 & 73.87 & 75.76 & $2.65 \mathrm{NS}$ \\
\hline $\mathbf{E E}$ & 20.66 & 19.59 & 18.60 & $1.06 \mathrm{NS}$ \\
\hline Ash & 5.44 & 6.53 & 5.63 & $0.34 \mathrm{NS}$ \\
\hline
\end{tabular}

$\mathrm{a}, \mathrm{b}, \mathrm{c}, \mathrm{d}, \mathrm{e}$ and $\mathrm{f}$ Means with different superscripts on the same row are different at $(\mathrm{P}<0.05)$. NS, not significant.

Weights of different organs fluctuated without exact trend indicating that dietary treatments did not harmfully affect any organ. Regarding total giblets weight (Table 4), the rabbits fed control diet recorded the highest value, while the least value was that of $50 \%$ JSM diet and $100 \%$ JSM diet was intermediate value. Non significant differences were noticed among the groups. Oladunjoye et al. (2014) reported that, the livers of rabbits that were fed control diet and $25 \%$ JSCM were similar in weight and larger $(\mathrm{P}<0.05)$ than those that were fed $50 \%$ and $75 \%$ JSCM. The spleen of the rabbits that were fed JSCM were smaller $(\mathrm{P}<0.05)$ than that of the group fed soybean meal as sole protein source.

Ccarcasses characteristics was not different between the control and treated groups; liver, heart and kidney observed in the rabbits of group that were fed diets containing 100\% JSCM replacing soybean meal were smaller than those of control diet but and $2.1 \mathrm{mg} / 100 \mathrm{ml}$, respectively, for NZW rabbits. Generally, the values obtained of blood constituents indicated normal physiological and healthy status of rabbits fed the experimental diets.

\section{Carcass characteristics:}

The differences in relative carcass traits as a result to the effect of feeding treatments were nonsignificant (Table 4). Under the condition of this experiment, it appears that, the highest values for dressing\% was recorded with rabbits fed diet containing 50 and $100 \%$ JSM compared to those fed control diet. These treatments had the best digestion coefficients, which are reflected on improving feed conversion and weight gain. In this respect, AbdelRahman et al. (2012) and Oladunjoye et al. (2014) reported that dressing\% of carcass of the rabbits that fed $50 \%$ JSM in replacement for soybean meal was higher $(\mathrm{P}<0.05)$ than that of the group fed control or other groups.

differences were not significant. This observation agrees with those of Abdel-Rahman et al., (2012) and Oladunjoye et al. (2014). Annongu et al. (2010) showed that organ weights in rats fed graded levels of JCSM in diets showed no significant differences $(\mathrm{P}<0.05)$ in absolute weights of the heart, lungs, liver and intestines compared with the organs of rats on the control diets.

\section{Photomicrographic of liver and kidney:}

No abnormalities in the histological structure of liver in rabbits fed diets containing (50 and 100\%) non toxic JSM or control diet (SBM), where hepatic architecture and hepatic lobules of histological structure of liver and also, no fatty liver, no necrosis or cellular degeneration were observed (Fig.1). Greaves (2007) reported that the criteria for assessing histo-pathological changes include architecture, inflammatory, necrosis, congestion, cloudy swelling. 


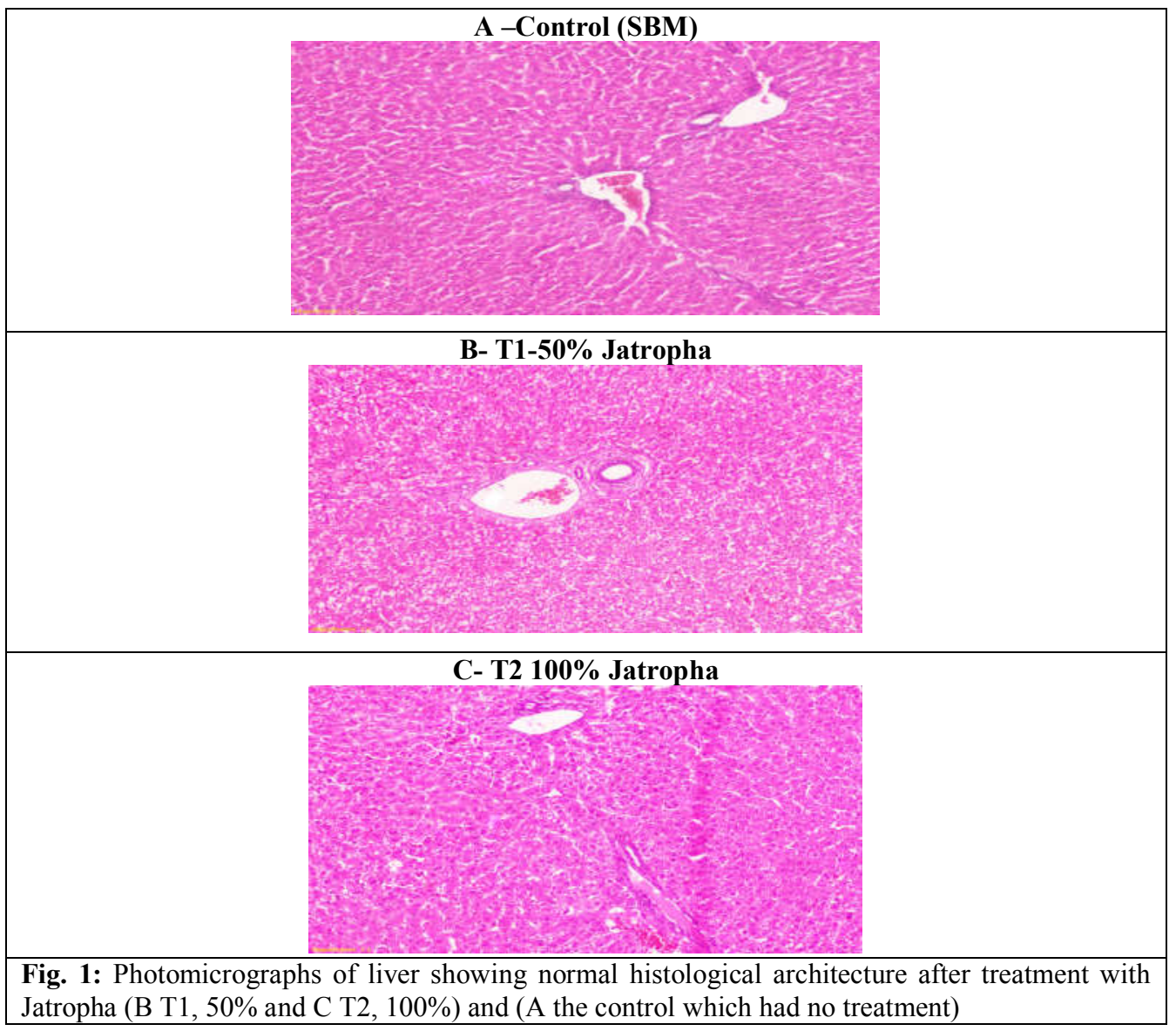

Concerning the morphological structure of the kidney in rabbits fed diets containing 50 and $100 \%$ JSM or control, there was no abnormalities cases;

there was only cloudy swelling to tubules in both treated and control groups (Fig.2).

\section{B-T1-50\%Jatropha}

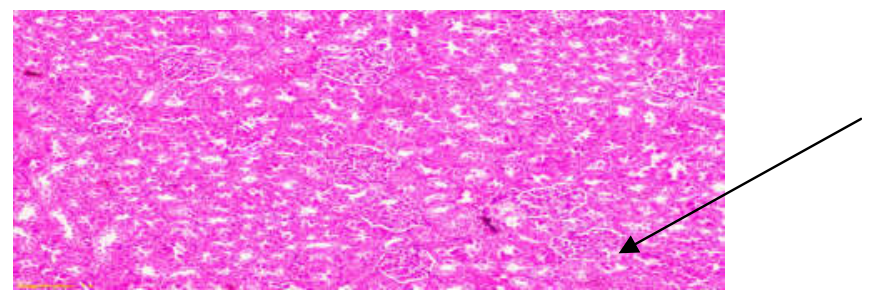

Photomicrographs of kidney in T1 (50\% Jatropha) group showing normal histological and only cloudy swelling to tubules. Section of the kidney of control rabbit showing normal appearance of glomerulus (black arrow).

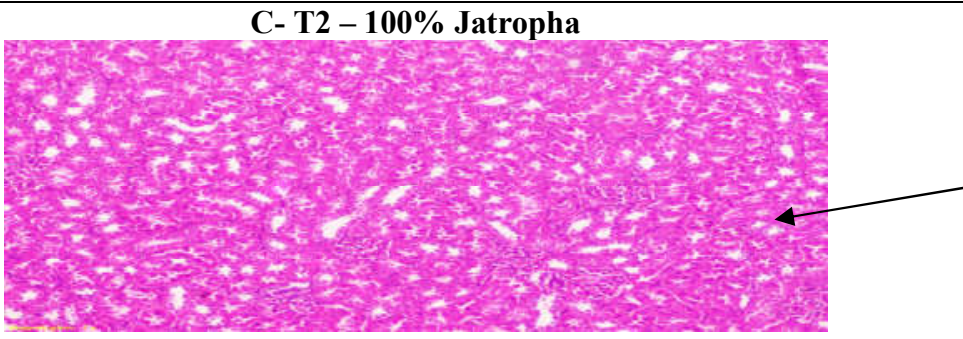

Fig. 2. Photomicrographs of kidney showing normal histological and there ware only cloudy swelling to tubules in both treated and control after treatment with Jatropha (B T1, 50\% and C T2, 100\%) and (A the control which had no treatment). Section of the kidney of control rabbit showing normal appearance of glomerulus (black arrow) 
In this respect, Orhue et al. (2008) reported that, the El-Manylawi, M. A.; M. R. M., Ibrahim; Ahmed, histopathology revealed that the heart, liver and kidney showed areas of mild necrosis. Although there was severe triaditis in the liver of the female treatment group compared with that of the male, such isolated event cannot sufficiently be interpreted as meaningful toxicological effect in rabbits given a 5 week repeated dose toxicity of Jatropha tanjorensis leave powder was carried out in rabbits.

\section{CONCLUSION,}

From the previous results, jatropha seed meal can be used up to 50 or $100 \%$ instead of soybean meal in the growing New Zealand rabbit diets without any adverse effects on carcass characteristics, cacum fermentation as well as kidney or liver function.

\section{REFERENCES}

Abdel-Rahman, K., H. Taie, A. Soliman and M.P. Assem, 2012. Performance of growing rabbits fed on some Agro-Industerial by-product. Egyptian J. Rabbit Sci., 22(1): 41-54.

Adjallo, K.M.; A.A. Koffuor; E.A. Asiamah; R. Annan-Dadzie and B. Osei-Donkor, 2017. Safety evaluation of honey from jatropha curcas nectar and its implication for honey production in Ghana. J. Food Microbiol Saf, Hyg. 1 2(3): 126.

Ahmed, Fatma G.; M. H. Yacout and F. M. AboDonia, 2005. Effect of using Eucalyptus Globulus leaves in growing rabbit diets. Egypt. J. of Rabbit Sci., 15(1)1-11.

Amao, O.A., 2009. Growth response and reproductive characteristics of rabbit buck fed cottonseed cake-based diets supplemented with vitamin E. Ph.D. Thesis, Ibadan Nigeria .Univ. J. Anim. Sci. Adv. 2 (10): 793-802.

Annongu, A.A.; J.K. Joseph; D.F. Apata; A.O. Adeyina; M.B. Yousuf and K.B. Ogunjimi, 2010. Detoxification of Jatropha curcas seeds for use in nutrition of monogastric livestock as alternative feedstuff. Pakistan J. Nutrition 9 (9): 902-904, 2010.

A.O.A.C., 2000. Association of Official Analytical Chemist's. Official methods of Analysis. $16^{\text {th }}$ Edition, Washington, D.C.

Bartles, H., 1972. Calorimetric determination of creatinine. Clin. Chem. Acta, 32: 81.

Dacie, J.V. and S.M. Lewis, 2000. Practical hematology. $4 \mathrm{Ed}$.

Doumas, B.T.; W., Watson and H. G., Biggs, 1971. Albumin standards and the measurement of serum albumin with bromocresol green. Clin. Chim. Acta, 31, 87.

Duncan, D.B., 1955. Multiple range and multiple Ftest. Biometrics, 11: 1-42.

Eadie, J.M.; P.N., Hobson and S.O. Mann, 1967. A note of some comparisons between the rumen content of barley fed steers and that of young calves also fed on high concentrate rations. J. Anim. Prod. 4:247.

Fatma G. and Salama, Walaa A., 2005. Performance of growing rabbits fed diets containing Geranium and spearmint by-products. Egypt. J. Rabbit Sci., 15(1) : 13-26.

El-Sayaad, G.; H.T., Taie and G.A. Baraghit 1996. Effect of dietary crude fiber level on performance, digestibility, carcass quality and blood constituents of growing rabbits. Egypt. J.Anim .Prod. 33(2):111-123.

Greaves, P., 2007. Histopathology of preclinical toxicity studies: interpretation and relevance in drug safety evaluation. $3^{\text {rd }}$ ed. Academic Press, New York.

Greiling, H. and A. M. Gressner, 1995. Lehrbuch der klinischen chemie und pathobiochemie. $3^{\text {rd }}$ Schattauer Verlag.

Habeeb, A.A.M.; A.F.M. Mare; A.M. El-Maghawry and A.E.Gad, 1997. Growing rabbits as affected by salinity in drinking water under winter and hot summer conditions of Egypt. Egyptian J. Rabbit Sci., 7 (2): 81 - 94.

Goel, G., H.P.S. Makkar, G. Francis and K. Becker, 2007. Phorbol esters: structure, occurrence and biological activity. Int. J. Toxicol., 26: 279-288.

Habeeb, Salwa M.; Heba M. Ashry; Faten A.M.; Abo- Aziza, A.A. Hala, Abou-Zeina and Fatma A. Morsy, 2014. Histopathological, Biochemical and Hematological Values in Rabbits Infested by the Camel Tick Hyalomma dromedarii (Acari: Ixodidae Middle-East J. of Sci. Research 22 (4): 537-544, 2014.

Hamoda, Shirinm 2010. chemical and techonological studies on jatropha seeds for the use in food industry. Phd . Thesis, Animal Production Dept., Faculty of Agriculture, Minufia University.

Henry, E.J., 1964. Colorimetric Determination of Total Protein and Calcium. Clin. Chem.Principles and Techniques. Harper - Row, Newark, P. 182.

Ifeanyi, Chukwuemeka, G.S. Utuk; P.C. Ugwu Okechukwu; U.A. Ibiam; P.M. Aja and C.E. Offor, 2015. The Effect of Ethanol Leaf Extract of Jatropha curcas on Some Haematological Parameters of Cyclophosphomide nduced Anaemia in Wister Albino Rats European J. of Appl. Scie. 7 (1): 17-20, 2015.

Koffuor, G.A; E. Woode; C. Obirikorang and E. Asiamah, 2011. ToxicityEvaluation of a Polyherbal Antihypertensive Mixture in Ghana. J. PharmBioall Sci. 1: 34-48.

Maity, S.; K. Sing ha and M. Singha, 2013. Three Dimensional Micro-image Analysis of Nonwoven Structure. Frontiers in Science, 3 (1): 22-26.

Makkar,. H.P.S; A.O. Aderibigbe and K..Becker, 1998. Comparative evaluation of non- toxic and toxic Jatropha curcas for chemical composition, digestibility, protein degradability and toxic factors. Food Chemistry. 62(2), :207-215.

Makkar H.P.S.and K..Becker, 1999. Plant toxins and detoxification methods to improve feed quality of tropical seeds. Asian Aust. J. Anim. Sci. 1999;12:467-480. 
Marty, M. and I., Vernay, 1984. Absorption and metabolism of volatile fatty acid in the hind gut of the rabbit Br. J . Nutr . ,51:265-277.

Mousa, A.M.Z., 2018. Utilization of some Medicinal plants wastes in animal nutrition $\mathrm{PhD}$. Thesis, Animal Production Dept., Faculty of Agriculture, Minufia University.

NRC, 1977. National Research Council. Nutrient Requirements of Rabbits. Washington, DC., U. S.A.

Oladunjoye, O.; O. O., Ojebiyi; T., Ojediran; A. B. Adeniyi and S.A. Shonibare, 2014. Evaluation of Jatropha (Jatropha curcas L.) Seed Cake Meal as Feed for Rabbit International J. of Agri. Innovations and Research 2, (6), ISSN (Online) 147
Orhue E.S.; M. Idu; J.E. Ataman and L.E. Ebite, 2008 Haematological and histopathological studies of Jatropha tanjorensis (J.L. Ellis and Soroja) leaves in rabbits. Asian Journal of Biological Sciences Volume 1 (2): 84-89.

Patton, C. J. and S.R. Grouch, 1977. Colorimetric determination of urea. Anal. Chem. 49, 464- 469.

Reitman,S. and S. Frankel, 1957. A calorimetric method for the determination of serum glutamic oxaloacetic and glutamic pyruvic transaminases. Amer. J.Clinc. Path., 28: 56.

Snedecor, G.W. and Cochran, W.G., 1982. Statistical Methods $.6^{\text {th }}$ Edition. Iowa State University Press. Ames. U.S.A.

\section{خواص الذبيحة و نشاط الأعور و تقديرات الام و الحالة الهستولوجية للأرانب النامية المذاة على كسب بذور الجاتروفا} كمال محمد عبد الرحمن ا، حمدي توفيق طايع ا، جمال أحمد براغيت ا، أحمد على محمد سليمان ، شيرين عبد الحميد ربيع ا اقسم الإنتاج الحيواني، كلية الزراعة، جامعة المنوفية، مصر، r ـ ـ معل بحوث الإتتاج الحيواني، مركز البحوث الزرراعية، جيزة، مصر

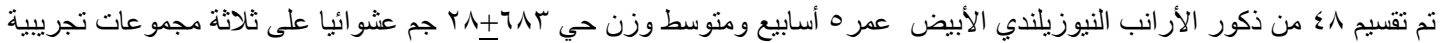

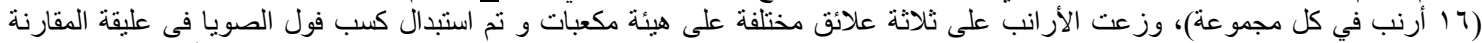

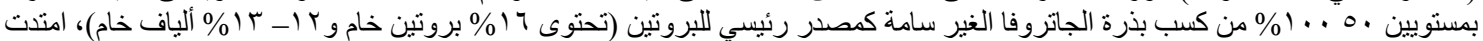

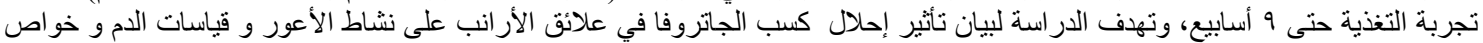
الذبيحة و الحالة المرضية.

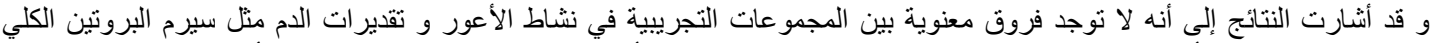

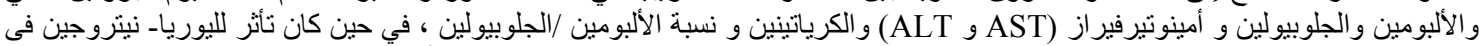

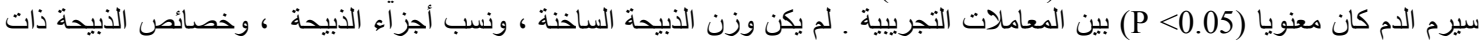

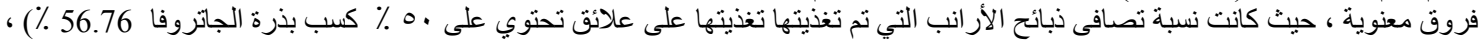

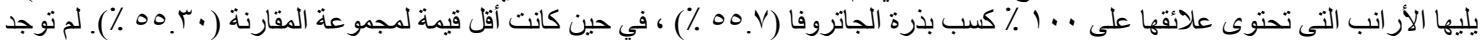

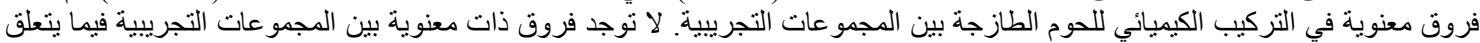

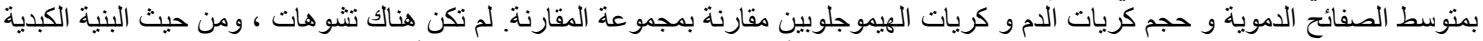

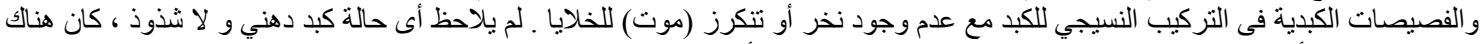

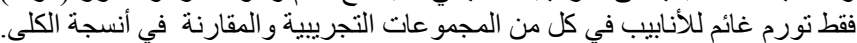

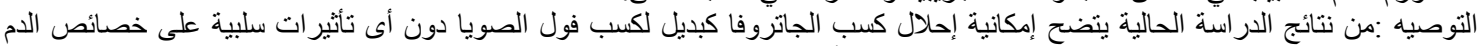

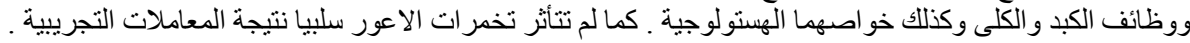

